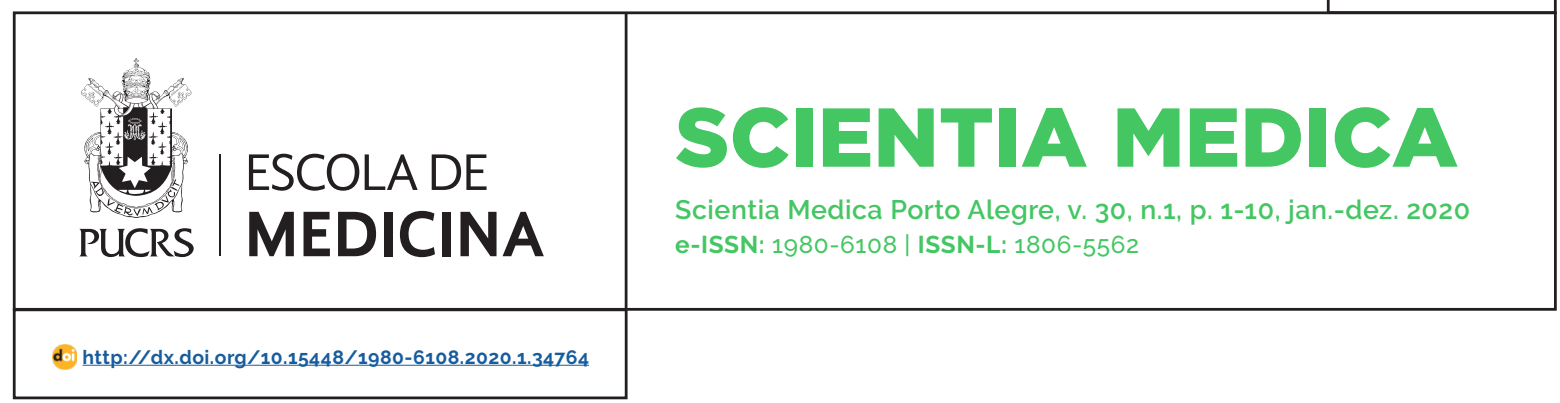

ORIGINAL ARTICLE

\title{
Enteroparasitosis in patients attended by the health public service: epidemiology and spatial distribution
}

\author{
Enteroparasitoses em pacientes atendidos pelo serviço público de saúde: \\ epidemiologia e distribuição espacial
}

\section{Andressa Barros \\ Ibiapina ${ }^{1}$ \\ orcid.org/0000-0002-3942-9117 \\ andressaibiapina@hotmail.com}

Janaina Soares Leal ${ }^{2}$

orcid.org/0000-0002-1885-4384

janaleves@hotmail.com

Pedro Ricardo

Alves de Santana ${ }^{3}$

orcid.org/0000-0003-4902-3847

pedrorikrdo@hotmail.com

\section{Marcelo Ribeiro \\ Mesquita ${ }^{4}$}

orcid.org/0000-0001-6315-0709

marcelomesquita@ifpi.edu.br

\section{Tito Lívio da}

Cunha Lopes 5

orcid.org/0000-0001-5555-5343

titolivio@ufpi.edu.br

\section{Débora Cavalcante \\ Braz $^{6}$}

orcid.org/0000-0001-5978-1241

deborabraz@ufpi.edu.br

Recebido em: 10 jul. 2019

Aprovado em: 16 nov. 2019

Publicado em: 25 mar. 2020

\section{Abstract:}

Aims: This research aims to determine the epidemiology and the spatial distribution of intestinal parasitosis in the city of Teresina, Brazil.

Methods: A cross-sectional study was carried out based on the data of parasitological fecal exams performed in the Laboratory Raul Bacelar between January 2014 and July, 2017. In addition to the prevalence of intestinal parasitosis and polyparasitism, we verified the association of these diseases with gender, zone and period of the year by means of the chi-squared test, whereas the relation with age was analyzed by the Mann-Kendall tests and multiple comparisons of age classes. The spatial distribution was performed using the QGIS georeferencing software. Results: The prevalence of enteroparasitosis in Teresina was $17.8 \%$ with Ascaris lumbricoides being the most common species. The prevalence of individuals with polyparasitism was 3.1\%, in which an association between the species Entamoeba coli and Entamoeba histolytica/dispar was found. There was no relation between intestinal parasitosis with gender, but we verified that individuals in rural areas were more susceptible to these diseases. The species Ascaris lumbricoides and Entamoeba histolytica/dispar occured more frequently in the first and second semester, respectively. We observed that there was an apparent tendency to increase cases of Entamoeba histolytica/dispar and reduction of cases of Giardia $s p$. according to aging. Mapping intestinal parasitosis showed us that there was a prevalence between 1 and $20 \%$ in most of Teresina's neighborhoods, and Ascariasis embodies at least $40 \%$ of cases of enteroparasitosis in these neighborhoods. Conclusions: Investments in basic sanitation and new epidemiological investigations must be carried out to control intestinal parasitosis in Teresina, emphasizing that children and the elderly should be considered priority groups in these programs.

Keywords: Epidemiology; geographic mapping; helminthiasis; neglected diseases; parasitic diseases; protozoan infections; sanitation.

\section{Resumo:}

Objetivo: Determinar a epidemiologia e a distribuição espacial das parasitoses intestinais no município de Teresina, Brasil.

Métodos: Foi realizado um estudo transversal com base nos resultados dos exames parasitológicos de fezes executados no laboratório Raul Bacelar, entre janeiro de 2014 e julho de 2017. Além da prevalência de parasitoses intestinais e de poliparasitismo, verificou-se a associação destas doenças com sexo, zona e período do ano, por meio do teste do qui-quadrado, enquanto a relação com a idade foi analisada pelos testes de Mann-Kendall e comparações múltiplas de faixas etárias. A distribuição espacial foi realizada utilizando o software de georreferenciamento QGIS.

Resultados: A prevalência de enteroparasitoses em Teresina foi de $17,8 \%$, sendo Ascaris lumbricoides a espécie mais comum. A prevalência de indivíduos com 
poliparasitismo foi de $3.1 \%$, na qual foi encontrada uma associação entre as espécies Entamoeba coli e Entamoeba histolytica/dispar. Não houve relação entre parasitoses intestinais e sexo, mas verificou-se que individuos na zona rural foram mais suscetiveis a essas doenças. As espécies Ascaris lumbricoides e Entamoeba histolytica/dispar ocorreram com maior frequência, respectivamente, no primeiro e no segundo semestre. Observou-se que houve aparente tendência de aumento de casos de E. histolytica/dispar e de redução de casos de Giardia sp. de acordo com o envelhecimento. O mapeamento das parasitoses intestinais demostrou que houve uma prevalência entre 1 e $20 \%$ na maioria dos bairros de Teresina, e a ascaridiase representou pelo menos $40 \%$ dos casos de enteroparasitose nesses bairros.

Conclusões: Investimentos em saneamento básico e novas investigações epidemiológicas devem ser realizados para o controle das parasitoses intestinais em Teresina, enfatizando que crianças e idosos devem ser considerados grupos prioritários nessas ações.

Palavras-chave: Epidemiologia; mapeamento geográfico; helmintiase; doenças negligenciadas; doenças parasitárias; infecções por protozoários; saneamento.

\section{INTRODUCTION}

Intestinal parasitosis are a group of diseases caused by protozoa and helminths that affect the gastrointestinal tract, transmitted through contact with contaminated soil or through ingestion of contaminated food or water [1,2]. The symptomatology provoked by intestinal parasitosis is varied and not very specific, including diarrhea, nausea, vomiting, and abdominal pain [3]. Individuals with high parasitic load or compromised immune system present more severe manifestations, such as intestinal obstruction and abscesses, which may culminate in the death of the host $[3,4]$.

Children and elderly people are more susceptible to the appearance of inherent complications in parasitosis. We emphasize that the consequences in children and teenagers are not limited to gastrointestinal symptoms, impairing cognitive and physical development [5]. Patients suffering from diseases that suppress the immune system, such as acquired immunodeficiency syndrome and cancer, also demand attention because of the increased mortality risk [6].

Despite having a wide knowledge about harms generated to the health of those affected, as well as harms on the economy, enteroparasitosis are considered neglected diseases [7]. The shortage of data makes it difficult to plan policies to reduce the number of infected individuals and makes it impossible to monitor the effects of actions taken [8]. In this sense, public initiatives must be oriented for specific groups in population.

The prevalence rates of intestinal parasitosis change according to the region of the country and are related to the health of local citizens in Brazil [9]. Basic sanitation, housing conditions and hygiene habits are factors associated with the incidence of intestinal parasitosis [10]. Therefore, we can comprehend that the environment influences on the appearance of these diseases since such aspects are determinants of the health of populations [11]. In this context, epidemiology contributes significantly to the understanding of the health-disease process dynamics by making it possible to identify the most affected groups and a disease spatial distribution [2,12].

Considering the importance and the shortage of data on the subject, this study aims to determine the prevalence, epidemiological characteristics and spatial distribution of intestinal parasitosis in patients attended by health public service of Teresina, in the state of Piaui, Brazil.

\section{METHODS}

\section{Study Area}

Teresina is the capital of the state of Piaui, which is located in the Northeast of Brazil. The city is located at $05^{\circ} 05^{\prime} 21^{\prime \prime} \mathrm{S}$ and $42^{\circ} 48^{\prime} 07^{\prime \prime} \mathrm{W}$ and has a total area of $1,392 \mathrm{~km}^{2}$. The climate of the city is characterized by the concentration of rainfall in the first four months of the year, so that the relative humidity of the air remains high during the first semester and suffers an intense reduction in the second half. The average annual temperature of Teresina corresponds to $27.7^{\circ} \mathrm{C}$, however the temperatures can increase a lot between August and December. The predominant types of soils in the region are yellow latosol and red-yellow podzolic, which present significant acidity [13]. The study population is composed of Teresina inhabitants who perform parasitological fecal exams through municipal public health establishments integrated by 12 hospitals and 90 Basic Health Units (BHU) distributed in urban and rural areas [14]. 


\section{Data Collection}

The present work consists of an observational and transversal study, developed through the analysis of data from parasitological fecal exams performed by the spontaneous sedimentation method (HoffmanPons-Janer technique) in Laboratory Raul Bacelar, which has collection points in the hospitals and the BHU of the city. All parasitological exams performed between January, 2014 and June, 2017 of patients residing in Teresina, without repetitions, were included in this study. The date of completion and the result of the parasitological examination, the age, the gender and the address of the patients were collected for analysis.

\section{Statistical Analysis}

The data were organized and submitted to statistical tests with the help of LibreOffice suite version 5.3.3.2 and $R^{\circledR} \times 64$ software version 3.4.4. The level of significancewas $5 \%$ forall tests. The prevalence of intestinal parasitosis in the study population and percentage of polyparasitism were determined by the corresponding relative frequencies, as well as the prevalence of enteroparasitosis per neighborhood. The existence of correlation between the species in polyparasitism was verified, and their association was analyzed through the chi-square test. Similarly, the chi-square test was performed to determine if there is any association between intestinal parasitosis and gender, zone (urban or rural) and period of the year. Regarding age, the prevalence of each age group was submitted to the Mann-Kendall test to investigate tendency and the multiple comparisons test by age class with the $p$-value adjusted by the Bonferroni method. The prevalence of intestinal parasitosis in neighborhoods of the urban area of Teresina was used to perform the mapping through the QGIS 2.18 georeferencing software.

\section{Ethics}

The research was approved by the Municipal Health Foundation of Teresina and by the Research Ethics Committee of the Federal University of Piaui (CAAE: 74508017.2.0000.5214. opinion number: 2.256.597). In order to ensure confidentiality, all patients involved in the study had their names replaced by codes referring to the request for examination.

\section{RESULTS}

39.539 parasitological exams from different individuals were included in the study. The majority of the investigated population consists of female subjects $(64.6 \%)$ and residents of the urban area of Teresina (96.4\%). 38,664 out of the total number of exams, had an age record, most of them were adults ( $49.1 \%$ ), followed by children (26.5\%), elderly (14.6\%) and teenagers (9.7\%).

The prevalence of intestinal parasitosis in patients attended by public health service of Teresina was equal to $17.8 \%$. Ascaris lumbricoides was the most frequent species of intestinal parasites in the population. Entamoeba coli, Entamoeba histolytica/dispar, Endolimax nana and Giardia sp. also stood out as common parasites (Table 1).

TABLE 1 - Prevalence of the most common intestinal parasite species in patients attended by the health public service of Teresina, Brazil.

\begin{tabular}{lcc}
\hline Species & Absolute frequency & Prevalence (\%) \\
\hline Ascaris lumbricoides & 3,127 & 8 \\
Entamoeba coli & 1,934 & 5 \\
Entamoeba histolytica/dispar & 1,380 & 3.5 \\
Endolimax nana & 915 & 2.3 \\
Giardia sp. & 879 & 2.2 \\
\hline
\end{tabular}


The other species found (Enterobius vermicularis, Hymenolepis nana, Hymenolepis nana, lodamoeba butschlii, Strongyloides stercoralis, Trichocephalus trichiuris, Balantidium coli, Trichomonas sp., Taenia sp. and hookworms) had a prevalence lower than $1 \%$. The percentage of polyparasitism obtained was $3.1 \%$, in which up to four different species were diagnosed in the gastrointestinal tract of the same individual. Simultaneous presence of Entamoeba histolytica/dispar and Entamoeba coli in the samples showed a higher correlation and an association between the species was verified by the chi-square test (Table 2 ).

TABLE 2 - Association between the species Entamoeba coli and Entamoeba histolytica/dispar according to the results of the parasitological tests carried out in the health public service of Teresina, Brazil.

\begin{tabular}{ccccc}
\hline & \multicolumn{3}{c}{ Entamoeba histolytica/dispar } & \\
Entamoeba coli & Positive & Negative & Total & p-value \\
\hline Positive, $\mathrm{n}(\%)$ & $1,022(74.1)$ & $912(2.4)$ & $1,934(4.9)$ & $<0.001$ \\
Negative, $\mathrm{n}(\%)$ & $358(25.9)$ & $37,247(97.6)$ & $37,605(95.1)$ & \\
Total & $1,380(100)$ & $38,159(100)$ & $39,539(100)$ & \\
\hline
\end{tabular}

Pearson's chi-square test for association.

Thus, the tests demonstrated that individuals parasitized by Entamoeba coli were 117 times more likely to have Entamoeba histolytica/dispar.

There was no association between intestinal parasitosis and gender $(p=0.912)$. The percentage of positive parasitological exams is $64.7 \%$ to female subjects and $34.4 \%$ to male subjects. Concerning negative parasitological exams, these percentages remain, which $64.6 \%$ are from female and $35.4 \%$ are from male subjects. The association between enteroparasitosis and the area of the city was confirmed ( $p=0.003$ ), with a higher proportion of cases in the rural area of Teresina (300 positive exams and 1,141 negative exams), where individuals are $22.4 \%$ more likely to have intestinal parasitosis in relation to urban patients (6,739 positive exams and 31,359 negative exams). As for seasonality, Ascaris lumbricoides showed higher frequency during the first semester (Table 3), while Entamoeba histolytica/dispar had a higher frequency in the second semester ( $p=0.003$ and $p=0.012$, respectively).

TABLE 3 - Association between the period of the year and the presence of intestinal parasitosis in Teresina, Brazil.

\begin{tabular}{lccc}
\hline Species & $\begin{array}{c}\mathbf{1}^{\text {st }} \mathbf{s e m e s t e r} \\
\mathbf{n}(\%)\end{array}$ & $\begin{array}{c}\mathbf{2}^{\text {nd }} \text { semester } \\
\mathbf{n}(\%)\end{array}$ & p-value \\
\hline Ascaris lumbricoides & $1,276(36.6)$ & $1,106(33.1)$ & 0.003 \\
Entamoeba coli & $826(23.7)$ & $797(23.9)$ & 0.868 \\
Entamoeba histolytica/dispar & $529(15.1)$ & $582(17.4)$ & 0.012 \\
Endolimax nana & $441(12.6)$ & $442(13.2)$ & 0.482 \\
Giardia sp. & $349(10)$ & $359(10.8)$ & 0.328 \\
Outras & $71(2)$ & $55(1.6)$ & 0.272 \\
Total & $3.492(100)$ & $3.341(100)$ & - \\
\hline
\end{tabular}


Regarding the age group, there was an apparent tendency to increase the occurrence of Entamoeba histolytica/dispar, as well as to reduce cases of Giardia sp. according to the advancement of age, with $p$-values close to 0.05 (Table 4).

TABLE 4 - Prevalence of each parasite species according to age group*.

\begin{tabular}{lccccc}
\hline Species & Children & Teenager & Adult & Elderly & p-value \\
\hline Ascaris lumbricoides & 8 & 7 & 7.9 & 8.4 & 0.734 \\
Entamoeba coli & $3.7^{\mathrm{c}, \mathrm{d}}$ & $3.5^{\mathrm{c}, \mathrm{d}}$ & $5.5^{\mathrm{a}, \mathrm{b}}$ & $6.2^{\mathrm{a}, \mathrm{b}}$ & 0.308 \\
Entamoeba histolytica/dispar & $2.1^{\mathrm{c}, \mathrm{d}}$ & $2.1^{\mathrm{c}, \mathrm{d}}$ & $4^{\mathrm{a}, \mathrm{b}, \mathrm{d}}$ & $5.3^{\mathrm{a}, \mathrm{b}, \mathrm{c}}$ & 0.089 \\
Endolimax nana & 1.9 & 2.7 & 2.4 & 2.4 & 1,0 \\
Giardia sp. & $3.5^{\mathrm{b}, \mathrm{c}, \mathrm{d}}$ & $2.4^{\mathrm{a}, \mathrm{d}}$ & $1.8^{\mathrm{a}}$ & $1.3^{\mathrm{a}, \mathrm{b}}$ & 0.089 \\
\hline
\end{tabular}

Data expresses as percentages.

Age categories: "Children" (ages 0-11), "Teenager" (12-17 years), "Adult" (18-59 years) and "Elderly" ( $\geq 60$ years), according to Brazilian Statute of the Child and Adolescent and Brazilian Statute of Elderly. Mann-Kendall test and Multiple comparison test with $\mathrm{p}$-value adjusted by the Bonferroni method. The combinations between the letters A-D (A: children, B: teenager, C: adult, D: elderly) represent two-to-two statistically significant comparisons by the multiple comparison test $(p<0.001)$.

The multiple comparisons test demonstrated, through two-to-two comparisons, that for Giardia $s p$. there was a statistically significant difference between the following age classes: children and teenager; children and adult; children and elderly; teenager and elderly ( $p<0.001$ ). For Entamoeba histolytica/dispar, comparisons were significant between children and adult; children and elderly; teenager and adult; teenager and elderly; adult and elderly $(p<0.001)$. For Entamoeba coli, there was a statistical difference for the comparisons between: children and adult; children and elderly; teenager and adult; teenager and the elderly $(p<0.001)$.

According to the mapping of intestinal parasitosis in the urban area of Teresina (Figure 1),

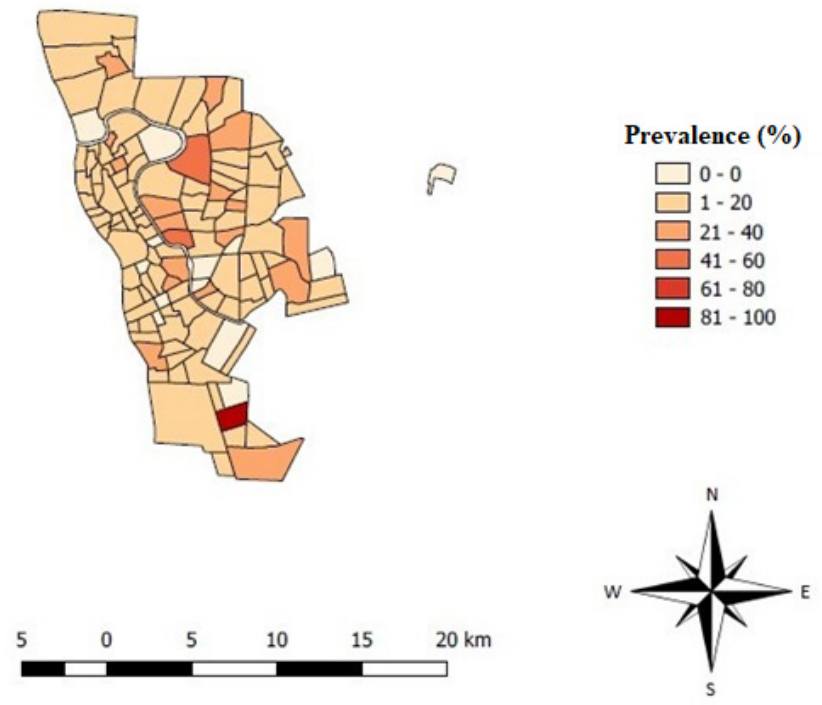

Figure 1 - Distribution of intestinal parasitosis per neighborhood of the city of Teresina from January, 2014 to June, 2017. 
$65 \%$ of the districts of the city presented prevalence between one and $20 \%$. The most prevalent neighborhoods were: Brasilar (100\%), Noivos (50\%), Zoobotânico (41.7\%), Cristo Rei (35.3\%), Jóquei (28.6\%), Recanto das Palmeiras (28.6\%), Monte Verde (27.6\%), Pedra Miúda (26.8\%), São Sebastião (26.7\%) and Memorare (26.4\%). The distribution of ascariasis among the parasitized population (Figure 2) showed that this infection represents more than $40 \%$ of the enteroparasitosis in most of the city districts (57\%). The districts of Colorado, Parque São João, Parque Sul, São Cristóvão and Parque Jacinta stood out as critical points in the urban area of the city, where ascariasis comprised more than $80 \%$ of the occurrences of intestinal parasitosis.

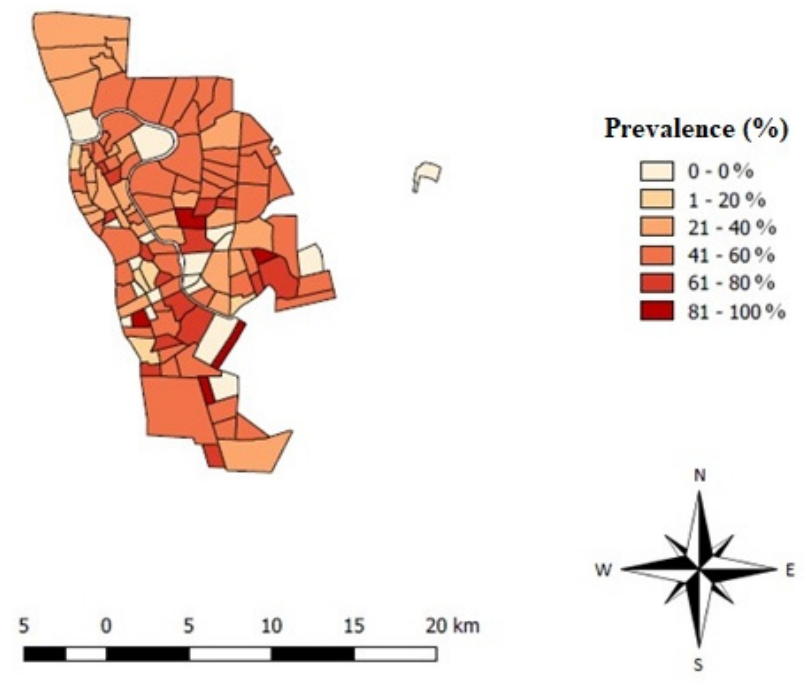

Figure 2 - Percentage of cases of Ascaris lumbricoides per neighborhood of the city of Teresina from January, 2014 to June, 2017.

\section{DISCUSSION}

The prevalence verified indicates that $17.8 \%$ of the studied population was infected by intestinal parasitosis from January, 2014 to June, 2017. This result can be justified by the precarious conditions of the basic sanitation of the city, mainly due to the sanitary sewage. According to the Brazilian Institute of Geography and Statistics, only $7.8 \%$ of households in Teresina had sewageconnected cesspits in 2017 [15]. As a result, higher prevalence of enteroparasitosis was expected, but some factors influence the percentage, such as the prophylactic administration of drugs and sensibility of Hoffman-Pons-Janer technique. The prophylactic administration of antiparasitic medicines can reduce prevalence of individuals parasitized in the city and, on the other hand, it can promotes reduction of the efficacy of drugs in the long term, as it has previously been observed to reduce the efficacy of mebendazole and albendazole, which has a decrease in its effectiveness against Trichocephalus trichiuris [16].

The comparison with other epidemiological investigations is difficult because of the varied populations, in which the majority of the studies are done with specific groups. However, the high prevalence of Ascaris lumbricoides is in agreement with a study carried out with elderly people from Parnaiba, state of Piauí, where 50\% of them were infected [17]. Ascariasis may have obtained high frequencies in relation to the other parasitic species due to the long life of the host, the release of approximately 200,000 eggs in the feces per day and the egg resistance to environmental conditions in the soil [18]. It is also important to consider the possibility of false-positive results because the Ascaris lumbricoides egg is very similar to artifacts such as plant cells that are common in the Brazilian diet and inexperienced analysts can misidentify 
them. The low prevalence of pathogenic protozoa Entamoeba histolytica/dispar and Giardia sp. when compared to Ascaris lumbricoides can be justified by the irregular elimination of cysts in feces, a limiting factor for the parasitological diagnosis besides the difficult identification in the microscopy [19]. Other enteroparasites were diagnosed sporadically (prevalence lower than 1\%) possibly due to the low specificity of the spontaneous sedimentation method for certain species, such as Enterobius vermicularis. In addition, the Teresina soil characteristics and the fragility of larvae in presence of sunlight also contribute to small number of hookworm cases recorded in this study [20].

The polyparasitism comprises simultaneous infections by different species of intestinal parasites and requires attention due to the increase in the morbidity of affected individuals. In this sense, although the prevalence of polyparasitism found is lower than that of monoparasitism, the potential health risks should be considered since it can lead to death in people with compromised immune system due to diseases such as acquired immunodeficiency syndrome or cancer. The form of transmission, environmental conditions and host behavior are possible causes for the association between Entamoeba histolytica/dispar infection and Entamoeba coli infection confirmed by the present study. This finding also shows the importance of the diagnosis of commensal parasites, given the great probability of acquiring pathogenic species. The association can be a consequence of morphological similarity between the species, which immunological tests are more reliable for differential diagnosis [21]. Another reason which explains the association could be intrinsic factors that need to be identified in future investigations.

There was no association between the positivity of parasitological tests and gender, so that the predominance of cases of intestinal parasitosis in female subjects is related to the profile of the study population, composed mainly of women. The area where patients reside, in turn, was associated with the frequency of these diseases. As observed in this research, rural inhabitants are more likely to acquire enteroparasitosis when compared to individuals living in the urban area, due to the absence or precariousness of basic sewage services, water supply and garbage collection, which makes such environment more conducive to the spread of these diseases [10].

The proportion of Ascaris lumbricoides cases was significantly higher in the first semester, which is explained by the agglomeration of rain at the beginning of each year in Teresina. The relationship between rainfall and Ascaris lumbricoides infection is due to the increase of atmospheric and soil humidity, favoring the development of the eggs eliminated in feces present in the soil [22]. Regarding protozoa, it was verified that there was a significant increase in the proportion of Entamoeba histolytica/dispar cases in the second semester, the season of the year in Teresina that has high temperatures and low humidity. This result corroborates with studies carried out in countries with a similar climate to Teresina, which have hot and dry summer, such as Jordan, where there is an increase in the incidence of intestinal parasitosis during the summer and Entamoeba histolytica is one of the most prevalent species in this season [23]. However, the predominantly fecal-oral transmission without the presence of cysts for long periods in the environment may be a more relevant factor for the prevalence of this disease, so that the climatic conditions are not a determining factor for the prevalence of amebiasis.

Among the most prevalent species of parasites in Teresina, Ascaris lumbricoides, Entamoeba coli and Endolimax nana did not show any tendency according to age. We highlight the unrestricted distribution of Ascaris lumbricoides by age groups in the investigated population, a feature that contributes to this enteroparasite being the most prevalent in the city. The apparent tendency to reduce the frequency of giardiasis with the increasing age, also observed in study carried out with patients in tertiary care hospital in India [24], results from the immunity acquired by individuals previously exposed to Giardia sp., which induces the production of specific antibodies and $C D 4^{+} \mathrm{T}$ memory cells [25]. As a result, children become 
more susceptible to Giardia sp. and have a significantly higher prevalence when compared to other age groups.

The most frequent enteroparasitosis among the elderly were concordant with another study carried out in Piauí in which protozoa, including Entamoeba histolytica/dispar, are the most prevalent [17]. The tendency of increasing the proportion of Entamoeba histolytica observed by the present research can be consequence of differences in the immune response against antigens of this parasite, in which the elderly present a significant increase of IL-19 and reduction of Eotaxin-2/CCL24 in relation to other age classes [26]. In addition, the dependence on the performance of instrumental activities of daily living, low schooling and the use of several medications concurrently common in this age group are factors that may favor the increase in the number of cases with aging [27]. The occurrence of Entamoeba histolytica/dispar in this population group reflects the number of cases of hospitalizations for amebiasis in individuals residing in Teresina between January, 2014 and June, 2017. According to the Department of Informatics of the Unified Health System, three out of the eight registered cases were hospitalizations of elderly people in an emergency, with an average of two to 3.5 days of stay in hospitals [28]. Considering that the symptoms of amebiasis include blood in stool, dysentery and potential dissemination of trophozoites in the organism causing extraintestinal complications, such as abscesses in the liver, this disease represents a risk to the health of the elderly population [29].

The mapping of intestinal parasitosis in patients attended by health public service of Teresina who live in the urban area of the city indicates that more than half of the districts of different areas have prevalence between one and $20 \%$, range that covers the prevalence of the city (17.4\%). This data shows that cases of enteroparasitosis are not concentrated in specific regions. The neighborhoods with the highest prevalence of intestinal parasitosis have a high percentage of households with rudimentary cesspits and/or low percentage of households connected to the general sewage network, evidencing the importance of sanitary sewage on the health of the population and the lack of politics based on health education in these areas. The high prevalence in some districts, despite good sanitation, may be a consequence of the reduced number of patient exams from these localities, which may have caused distortion in the results. The distribution of Ascaris lumbricoides cases confirms the intense prevalence of this helminth in the city and shows the deficiency of basic sanitation conditions in neighborhoods located in the periphery, mainly in the South and East of Teresina.

In conclusion, ascariasis is the most prevalent enteroparasitosis with a uniform spatial distribution throughout the city. Children and elderly are significantly more parasitized by Giardia sp. and Entamoeba histolytica/dispar, respectively, therefore they should be a priority in the planning of actions. Investments in basic sanitation and health education measures are important strategies to promote the reduction of the prevalence of intestinal parasitosis. New epidemiological investigations need to be carried out in order to monitor the health conditions of the population and the efficiency of the policies adopted.

\section{Notes}

\section{Funding}

This study did not receive financial support from external sources

\section{Conflicts of interest disclosure}

The authors declare no competing interests relevant to the content of this study.

\section{Authors' contributions.}

All the authors declare to have made substantial contributions to the conception, or design, or acquisition, or analysis, or interpretation of data; and drafting the work or revising it critically for important intellectual content; and to approve the version to be published.

\section{Availability of data and responsibility for the results}

All the authors declare to have had full access to the available data and they assume full responsibility for the integrity of these results. 


\section{REFERENCES}

1. Pereira EBS, Rodrigues SLC, Bahia-de-Oliveira GH, Coelho SVB, Barata RA. Detection of intestinal parasites in the environments of a public school in the town of Diamantina, Minas Gerais State, Brazil. Rev Inst Med Trop Sao Paulo. 2016; 58:51. http://dx.doi. org/10.1590/S1678-9946201658051.

2. Fonseca ES, Carvalho GLX, Nicolato RLC, Machado-Coelho GLL, Moura ACM. Análise espacial dos casos de enteroparasitas em Ouro Preto, entre 1995 e 2000 . Rev Bras Geografia Médica e da Saúde. 2010; 6(10):28-34.

3. Braz AS, Andrade CAF, Mota LMH, Lima CMBL. Recomendações da Sociedade Brasileira de Reumatologia sobre diagnóstico e tratamento das parasitoses intestinais em pacientes com doenças reumáticas autoimunes. Rev Bras Reumatol. 2015; 55(4):368-80. http://dx.doi.org/10.1016/j.rbr.2014.10.010.

4. Santos SA, Merlini LS. Prevalência de enteroparasitoses na população do municipio de Maria Helena, Paraná. Cien Saude Colet. 2010; 15(3):899-905. http:// dx.doi.org/10.1590/S1413-81232010000300033.

5. Choi B, Kim B. Prevalence and risk factors of intestinal parasite infection among schoolchildren in the peripheral highland regions of Huanuco, Peru. Osong Public Health Res Perspect. 2017; 8(5):302-7. https:// doi.org/10.24171/j.phrp.2017.8.5.03.

6. Jeske S, Bianchi TF, Moura MQ, Baccega B, Pinto NB, Berne MEA, Villela MM. Intestinal parasites in cancer patients in the South of Brazil. Braz. J. Biol. 2018; 78(3):574-78. http://dx.doi.org/10.1590/15196984.175364

7. Gil FF, Busatti HGNO, Cruz VL, Santos JFG, Gomes MA. High prevalence of enteroparasitosis in urban slums of Belo Horizonte-Brazil. Presence of enteroparasites as a risk factor in the family group. Pathog Glob Health. 2013; 107(6):320-4. https://doi.org/10.117 9/2047773213Y.0000000107.

8. Andrade EC, Leite ICG, Rodrigues VO, Cesca MG Parasitoses intestinais: uma revisão sobre seus aspectos sociais, epidemiológicos, clínicos e terapêuticos. Rev APS. 2010; 13(2):231-40.

9. Belo VS, Oliveira RB, Fernandes PC, Nascimento BWL, Fernandes FV, Castro CLF, Santos WB, Silva ES. Fatores associados à ocorrência de parasitoses intestinais em uma população de crianças e adolescentes. Rev Paul Pediatr. 2012; 30(2):195-201. http:// dx.doi.org/10.1590/S0103-05822012000200007.

10. Sinniah B, Hassan AKR, Sabaridah I, Soe MM, Ibrahim Z, Ali O. Prevalence of intestinal parasitic infections among communities living in different habitats and its comparison with one hundred and one studies conducted over the past 42 years (1970 to 2013) in Malaysia. Trop Biomed. 2014; 31(2):190-206.
11. Maia CVA, Hassun IC, Valladares GS. Fatores sociossanitários e parasitoses intestinais em Limoeiro do Norte, CE. Revista Brasileira de Geografia Médica e da Saúde. 2014; 10(19):50-64.

12. Gelaw A, Anagaw B, Nigussie B, Silesh B, Yirga A, Alem M, Endris M, Gelaw B. Prevalence of intestinal parasitic infections and risk factors among schoolchildren at the University of Gondar Community School, Northwest Ethiopia: a cross-sectional study. BMC Public Health. 2013; 13:304. https://doi. org/10.1186/1471-2458-13-304.

13. Secretaria Municipal de Planejamento - Teresina. Caracterização do Município [Internet]. Teresina; 2016 [cited 2018 June 30]. Available from: http://semplan. teresina.pi.gov.br/wp-content/uploads/2016/08/ TERESINA-Caracterização-do-Municipio.pdf

14. Fundação Municipal de Saúde de Teresina - FMS Laboratório Raul Bacelar - Fundação Municipal de Saúde de Teresina - FMS [Internet]. Teresina; 2015 [cited 2018 June 30]. Available from: http://fms.teresina.pi.gov.br/laboratorio-raul-bacelar/

15. Instituto Brasileiro de Geografia e Estatistica - IBGE. Pesquisa Nacional por Amostra de Domicilios Contínua - PNAD Contínua [Internet]. Brasilia; 2017 [cited 2018 July 18]. Available from: https://www.ibge.gov.br/ estatisticas-novoportal/sociais/trabalho/17270-pnad-continua.html?edicao=20915\&t=resultados $/$

16. Moser W, Schindler C, Keiser J. Efficacy of recommended drugs against soil transmitted helminths: systematic review and network meta-analysis. BMJ. 2017; 358(J4307):1-10. https://doi.org/10.1136/bmi.j4307.

17. Furtado LFV, Melo ACFL. Prevalência e aspectos epidemiológicos de enteroparasitoses na população geronte de Parnaiba, Estado do Piaui. Revista da Sociedade Brasileira de Medicina Tropical. 2011; 44(4):513-15. http://dx.doi.org/10.1590/S003786822011000400023 .

18. Dold C, Holland CV. Ascaris and ascariasis. Microbes and Infection. 2011; 13(7):632-37. https:// doi. org/10.1016/j.micinf.2010.09.012.

19. Garcia LS. Practical guide to diagnostic parasitology. 2nd ed. Washinghton, DC: American Society for Microbiology; 2009.

20. Mabaso MLH, Appleton CC, Hughes JC, Gouws E. The effects of soil type and climate on hookworm (Necator americanus) distribution in KwaZulu-Natal, South Africa. Tropical Medicine and International Health. 2003; 8(8):722-27. https://doi.org/10.1046/j. 1365-3156.2003.01086.x.

21. Silva MCM, Monteiro CSP, Araújo BAV, Silva JV, Póvoa MM. Determinação da infecção por Entamoeba histolytica em residentes da área metropolitana de Belém, Pará, Brasil, utilizando ensaio imunoenzimático (ELISA) para detecção de antígenos. Cad. Saúde Pública. 2005; 21(3):969-73. http://dx.doi. org/10.1590/S0102-311X2005000300033. 
22. Schüle SA, Clowes P, Kroid I, Kowuor DO, Nsojo A, Mangu C, Riess H, Geldmacher C, Laubender RP, Mhina S, Maboko L, Löscher T, Hoelscher M, Saathoff E. Ascaris lumbricoides Infection and Its Relation to Environmental Factors in the Mbeya Region of Tanzania, a Cross-Sectional, Population-Based Study. Plos One. 2014; 9(3):1-10. https://doi.org/10.1371/ journal.pone.0092032.

23. Jaran AS. Prevalence and seasonal variation of human intestinal parasites in patients attending hospital with abdominal symptoms in northern Jordan. Eastern Mediterranean Health Journal. 2016; 22(10):756-60.

24. Praharaj I, Sarkar R, Ajjampur SSR, Roy S, Kang G. Temporal trends of intestinal parasites in patients attending a tertiary care hospital in south India: A seven-year retrospective analysis. Indian J Med Res. 2017; 146(1):11120. https://dx.doi.org/10.4103/ijmr.IJMR_1236_14.

25. Hanevik K, Kristoffersen E, Svard S, Bruserud O, Ringqvist E, Sernes S, Langeland N. Human Cellular Immune Response Against Giardia lamblia 5 Years After Acute Giardiasis. The Journal of Infectious Diseases. 2011; 204(11):1779-86. https://doi.org/10.1093/ infdis/jir639.

26. Lechner CL, Komander K, Hegewald J, Huang X, Gantin RG, Soboslay PT, Agossou A, Banla M, Köhler C. Cytokine and chemokine responses to helminth and protozoan parasites and to fungus and mite allergens in neonates, children, adults, and the elderly. Immunity \& Ageing. 2013; 10(29):1-10. https://doi. org/10.1186/1742-4933-10-29.

27. Santos PHS, Barros RCS, Gomes KVG, Nery AA, Casotti CA. Prevalência de parasitoses intestinais e fatores associados em idosos. Rev. Bras. Geriatr. Gerontol. 2017; 20(2):244-54. http://dx.doi. org/10.1590/1981-22562017020.160137.

28. Departamento de Informática do Sistema Único de Saúde - DATASUS. TabNet Win32 3.0: Morbidade Hospitalar do SUS - por local de residência - Piauí [Internet]. Brasilia; 2018 [cited 2018 July 22]. Available from: http://tabnet.datasus.gov.br/cgi/deftohtm. exe?sih/cnv/nrpi.def

29. Faust DM, Guillen N. Virulence and virulence factors in Entamoeba histolytica, the agent of human amoebiasis. Microbes and Infection. 2012; 14(15):142841. https://doi.org/10.1016/j.micinf.2012.05.013.

\section{Correspondence:}

\section{Andressa Barros Ibiapina}

Universidade Federal do Piaui, Campus Universitário Ministro Petrônio Portella, s/n, Bairro Ininga, Teresina - PI, 64049-550 